\title{
Emission inventories of primary particles and pollutant gases for China
}

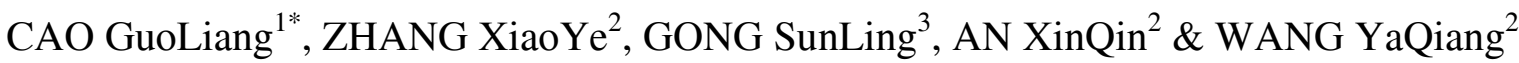 \\ ${ }^{1}$ School of Environmental and Municipal Engineering, Xi'an University of Architecture \& Technology, Xi'an 710055, China; \\ ${ }^{2}$ Chinese Academy of Meteorological Sciences, China Meteorological Administration, Beijing 100081, China; \\ ${ }^{3}$ Air Quality Research Division, Environment Canada, Toronto M3H 5T4, Canada
}

Received May 13, 2010; accepted October 11, 2010

\begin{abstract}
Detailed high-resolution emission inventories of primary particles $\left(\mathrm{PM}_{2.5}, \mathrm{BC}\right.$ and $\left.\mathrm{OC}\right)$ and pollutant gases $\left(\mathrm{SO}_{2}, \mathrm{NO}_{x}, \mathrm{NH}_{3}, \mathrm{CO}\right.$ and VOCs) for China in 2007 were constructed on the basis of the latest fuel consumption data, mostly at the county level, and from socio-economic statistics and data on fossil and biomass fuels obtained from government agencies. New emission factors reflecting local features were also used. The calculated emissions were $13.212 \mathrm{Mt} \mathrm{PM}_{2.5}, 1.4 \mathrm{Mt} \mathrm{BC}, 2.946 \mathrm{Mt}$ OC, $31.584 \mathrm{Mt}$ $\mathrm{SO}_{2}, 23.248 \mathrm{Mt} \mathrm{NO}_{x}, 16.017 \mathrm{Mt} \mathrm{NH}_{3}, 164.856 \mathrm{Mt} \mathrm{CO}$ and 35.464 Mt VOCs. The national and regional emissions were gridded with $0.5^{\circ} \times 0.5^{\circ}$ resolution for use in air quality models. Larger emissions were found in eastern and central China than in western China. The emissions estimated here are roughly equal to those obtained in previous studies, but with different contributions from because of seasonal changes in residential heating and biomass combustion. Finally, uncertainties in inventories were analyzed.
\end{abstract}

China, primary particle, pollutant gas, emission inventory, seasonality

Citation: Cao G L, Zhang X Y, Gong S L, et al. Emission inventories of primary particles and pollutant gases for China. Chinese Sci Bull, 2011, 56: 781-788, doi: $10.1007 / \mathrm{s} 11434-011-4373-7$

An accurate description of China's regional emissions in terms of the temporal and spatial distributions of particulate matter (PM) and pollutant gases is important for the modeling of regional environmental quality, pollution prevention, environmental policy development and climate effect research [1-3]. Because of their impacts on human health, air quality and climate, the importance of PM and pollutant gases has been recognized by scientists worldwide [4-6]. $\mathrm{SO}_{2}, \mathrm{NO}_{x}$ and $\mathrm{NH}_{3}$ are the reactive gases most critical in acid deposition [7-9]. Combining with $\mathrm{CO}$ and VOCs, they are also important precursor gases to form secondary aerosols in the atmosphere and are largely responsible for the reduced visibility and formation of haze. VOCs, CO and $\mathrm{NO}_{x}$ are the most important precursors in the formation of $\mathrm{O}_{3}$ and photochemical pollution [10].

$\mathrm{PM}$, black carbon (BC), organic carbon (OC), $\mathrm{SO}_{2}, \mathrm{NO}_{x}$

*Corresponding author (email: caoguoliang@xauat.edu.cn) and $\mathrm{CO}$ are mainly emitted in combustion processes, in particular, the burning of coal and biomass. About $97 \%$ of all $\mathrm{PM}_{2.5}, 90 \%$ of $\mathrm{SO}_{2}, 70 \%$ of $\mathrm{NO}_{x}$ and $32 \%$ of $\mathrm{CO}$ are produced in the combustion of coal [11-17]. $\mathrm{NH}_{3}$ is mainly released by agricultural processes (about 20\%-33\% of the total $\mathrm{NH}_{3}$ ) and animal decomposition of organic matter (about 50\%-60\%) [18,19]. VOC emission sources are more complex and mainly relate to transport, solvent evaporation and waste disposal $[12,20]$. Located in East Asia, China has a large area with a relatively non-modern economy and lifestyle and extensive use of coal and biomass as fuels, and a high level of poultry and livestock feeding with less advanced waste disposal methods. All these factors contribute to large emissions of particles and pollution gases to the global environment [3,17,21-24]. Because of China's unique geographical location and rapid economic development, changes in China's emissions (annual, seasonal, and monthly changes) are large and yet difficult to accurately 
estimate.

In the 1990s, foreign scholars systematically studied East Asian (mainly Chinese) emissions [3,17,23-28], but these studies involved great uncertainty owing to the lack of detailed information on China, especially important data on emission factors. Simulation and experimental studies have shown that these estimates, including the Streets' emission inventories, may be underestimated by $50 \%$ [29] for some species. In particular, the absence of data on China's rural and township industries introduces large uncertainty into the emission inventories. In addition, some emission inventories did not take into account seasonal variations, especially those in biomass combustion in rural China. Because of the heavy pollution of PM and acid rain in China, some national scholars have begun to construct emission inventories of PM and pollutant gases $[11,13,15,16,18,19,30-34]$. However, many of these studies did not give a spatial and temporal distribution, and thus, it is difficult to support a numerical simulation for comprehensive analysis of the situation of China's emissions at the required spatial and temporal resolution.

On the technical front of the emission inventories, many scholars have carried out much pioneering work [3,20,35]. Some domestic emission inventories have focused on information relating to technology and equipment [12]. As more domestic emission experiment data have become available, the uncertainty in inventories has tended to reduce.

In this work, to meet the needs of the National Key Basic Research Development Program (Aerosols over China and their Climate Effect) for numerical simulations, the emissions of $\mathrm{PM}_{2.5}, \mathrm{BC}, \mathrm{OC}$ and pollution gases $\mathrm{SO}_{2}, \mathrm{NO}_{x}, \mathrm{NH}_{3}$, $\mathrm{CO}$ and VOCs from mainland China (excluding Hong Kong, Macao and Taiwan) were estimated with fine spatial and temporal resolutions.

\section{Methodology}

Emission inventories are obtained using the level of emissions in different regions and for various types of sources. The general approach to estimate emissions of $\mathrm{PM}_{2.5}, \mathrm{BC}$, $\mathrm{OC}, \mathrm{SO}_{2}, \mathrm{NO}_{x}, \mathrm{CO}$ and VOCs employs an equation described by Klimont et al. [20]:

$$
E=\sum_{j} \sum_{k} \sum_{l} A_{j, k, l} E F_{j, k, l}\left(1-\eta_{j, k, l}\right),
$$

where $E$ is the emission, $A$ is the activity rate, $E F$ is the emission factor and $\eta$ is the removal efficiency; the subscripts $j, k$ and $l$ indicate the region, sector and fuel/activity type, respectively.

Emissions from forest and grassland fire are calculated as

$$
E=\sum_{j} A_{j} B_{j} C_{j} E F_{j},
$$

where $E$ is the emission, $A$ is the burning area, $B$ is the fuel load, $C$ is the burning efficiency and $E F$ is the emission factor; $j$ indicates the region.

$\mathrm{NH}_{3}$ emission is calculated using

$$
E_{i}=\sum_{j} L_{j} E f_{i, j}+\sum_{k}\left(E f_{i, k} F C_{i, k}+E f_{i, k} F P_{i, k}\right)+\sum_{l} F L_{l} E f_{i, l},
$$

where $L$ is the animal population, $F C$ is the fertilizer consumption, $F P$ is the fertilizer production, $E f$ is the emission factor and $F L$ is the fuel consumption. $i, j$ and $l$ indicate the region, livestock and poultry type, and fertilizer type and fuel type.

\subsection{Emission sources}

Emission source types in this work include biomass combustion (open burning of agricultural waste and forest and grassland fires), residences, power generation, industry, transportation, livestock and poultry breeding, fertilizer use, waste disposal, solvent use, and light industrial product manufacture. Emission sources are divided into two major categories: point sources and area sources.

A total of 383 large point sources were accounted for in this inventory, covering mainly power plants with generating capacity greater than 6.0 MW [36], while small power plants and power plants that are about to be decommissioned or modified were not included in the statistics. These large point sources are located mainly in eastern China and their main fuel is coal. A total of 98 large fertilizer manufacturing firms (http://www.chinafuhefei.com/) and 23 petrochemical manufacturers with processing capacity over 5 million tons (http://www.cpcic.com.cn/ html/), also located mainly in eastern China, were considered. Each point source is entered with the latitude and longitude of the address identification. Area sources include all stationary sources that are not included in the point-source category. The base year for the estimation in this work is 2007 .

\subsection{Emission factors}

In most cases, the emission factors are simply obtained from averaged data under an acceptable condition, which is not recommended for all standards or limits of sources of emission. There are many direct experimental measurements of emission factors of PM and pollutant gases emitted in fuel combustion around the globe, but experimental work in China is still very limited. The emission factors in this work mainly relate to domestic and foreign research results $[3,11,12,15-18,20,22,31,32,35,37-41]$, and we also cited relatively new experimental results [13,42-49], especially in the calculation of emissions from biomass combustion and motor vehicle emissions and VOC emissions. The sulfur content of domestic coal and oil and the proportion of $\mathrm{SO}_{2}$ produced in the burning of fuel were taken from the research results of Luo [50] and Arndt [51]. Since a large 
number of emission factors were considered in this work (e.g. more than 100 factors for VOCs), they are not all listed in this paper (this data is available on request).

\subsection{Basic data}

The basic data used to estimate emissions, such as population, area, gross domestic product, industrial output, fuel usage, vegetative cover, meteorological data and soil $\mathrm{pH}$, were taken from the National Bureau of Statistics and other government agencies, mostly at county level. Fossil fuels including coal, oil, natural gas, liquefied gas and coal are China's main energy fuels [52]. Biomass fuels include straw and firewood, and are used mainly for cooking and heating in rural areas [53]. Emission factors for the open burning of biomass were obtained from related research results [54]. Emissions from forest fires [55] and grass fires [56] were estimated from relevant data of the fuel load [57] and combustion efficiency $[57,58]$. The number of poultry livestock [56], chemical fertilizer application [56], various daily pro- duction capacities, number of motor vehicles, waste disposal and other public data were obtained from national statistical offices [52].

\section{Results and discussion}

\subsection{National and regional emissions}

The national and regional emissions of primary particles and pollutant gases in China for 2007 are listed in Table 1. Large provincial contributions are observed for Shandong, Hebei, Shanxi, Henan and Sichuan because these regions have high rural population densities and coal consumption. Higher coal consumption, especially coal burned in uncontrolled or poorly controlled coal-fired boilers, kilns and furnaces in rural industry result in higher emissions, while high rural population densities result in higher emissions from biomass and coal combustion in the residential sector. Owing to low coal consumption and lower rural population densities, emissions from western China (Qinghai, Gansu

Table 1 Provincial emission inventories for $2007\left(10^{4} \mathrm{t}\right)$

\begin{tabular}{|c|c|c|c|c|c|c|c|c|}
\hline Area & $\mathrm{PM}_{2.5}$ & $\mathrm{BC}$ & $\mathrm{OC}$ & $\mathrm{SO}_{2}$ & $\mathrm{NO}_{x}$ & $\mathrm{NH}_{3}$ & $\mathrm{CO}$ & VOCs \\
\hline Beijing & 16.2 & 2.3 & 4.2 & 17.2 & 43.7 & 11.7 & 199.8 & 74.4 \\
\hline Tianjin & 15.1 & 1.5 & 3.0 & 26.3 & 33.7 & 10.2 & 162.5 & 46.7 \\
\hline Hebei & 117.2 & 11.2 & 23.5 & 231.8 & 163.4 & 99.4 & 1266.9 & 232.7 \\
\hline Shanxi & 116.0 & 9.3 & 17.9 & 219.0 & 116.9 & 40.0 & 1319.3 & 161.7 \\
\hline Inner Mongolia & 46.1 & 5.6 & 12.2 & 104.7 & 115.9 & 50.8 & 520.4 & 95.5 \\
\hline Liaoning & 58.3 & 6.2 & 11.6 & 123.6 & 108.7 & 62.4 & 675.5 & 201.0 \\
\hline Jilin & 32.1 & 4.3 & 9.2 & 33.2 & 56.2 & 60.1 & 445.5 & 89.2 \\
\hline Heilongjiang & 38.6 & 4.8 & 11.9 & 26.4 & 69.1 & 40.0 & 570.3 & 157.5 \\
\hline Shanghai & 20.6 & 1.9 & 2.9 & 54.9 & 50.9 & 8.3 & 193.0 & 99.0 \\
\hline Jiangsu & 69.0 & 6.0 & 15.3 & 137.9 & 162.3 & 88.8 & 801.0 & 240.9 \\
\hline Zhejiang & 34.2 & 3.3 & 5.8 & 87.1 & 107.6 & 30.3 & 421.8 & 153.6 \\
\hline Anhui & 51.4 & 5.9 & 14.6 & 90.6 & 75.7 & 70.0 & 732.7 & 102.6 \\
\hline Fujian & 26.2 & 2.4 & 4.2 & 51.6 & 55.4 & 27.7 & 305.6 & 96.0 \\
\hline Jiangxi & 26.2 & 2.6 & 5.0 & 87.5 & 40.5 & 39.2 & 309.3 & 112.2 \\
\hline Henan & 93.2 & 9.6 & 22.4 & 234.2 & 147.1 & 138.5 & 1149.3 & 183.4 \\
\hline Hubei & 62.5 & 6.4 & 13.7 & 98.4 & 85.1 & 64.9 & 748.7 & 101.4 \\
\hline Hunan & 52.6 & 5.7 & 10.8 & 165.1 & 72.1 & 64.7 & 653.6 & 94.4 \\
\hline Guangdong & 47.3 & 5.5 & 8.4 & 153.6 & 153.6 & 77.7 & 665.5 & 279.0 \\
\hline Guangxi & 36.1 & 4.5 & 8.9 & 182.6 & 51.5 & 66.0 & 609.4 & 117.9 \\
\hline Hainan & 4.1 & 0.5 & 0.7 & 9.6 & 11.3 & 9.9 & 44.9 & 10.9 \\
\hline Chongqing & 16.0 & 2.1 & 4.3 & 109.8 & 30.4 & 26.6 & 263.5 & 45.3 \\
\hline Sichuan & 55.7 & 7.3 & 18.5 & 91.5 & 80.7 & 106.8 & 865.4 & 168.9 \\
\hline Guizhou & 38.1 & 5.6 & 9.9 & 178.8 & 63.9 & 44.5 & 539.5 & 84.2 \\
\hline Yunnan & 34.1 & 3.7 & 6.9 & 56.5 & 55.4 & 58.0 & 466.4 & 94.0 \\
\hline Tibet & 6.8 & 0.4 & 0.7 & 18.5 & 9.9 & 19.8 & 13.5 & 2.9 \\
\hline Shaanxi & 33.9 & 3.7 & 7.9 & 104.4 & 54.6 & 34.3 & 463.5 & 82.5 \\
\hline Gansu & 22.3 & 2.6 & 6.2 & 28.8 & 31.6 & 30.7 & 252.9 & 60.8 \\
\hline Xinjiang & 19.5 & 2.3 & 4.9 & 31.5 & 35.1 & 32.6 & 265.5 & 53.5 \\
\hline Total & 1321.2 & 139.9 & 294.6 & 3158.4 & 2324.8 & 1601.7 & 16485.6 & 3546.4 \\
\hline
\end{tabular}


and Tibet) and Inner Mongolia are lower.

Figure 1 shows the gridded primary particle and pollutant gases emissions for the year 2007 at $0.5^{\circ} \times 0.5^{\circ}$ resolution for $\mathrm{BC}$ and $\mathrm{NH}_{3}$. As most of the basic data are at county level, we can better localize the emissions on higher resolution maps in many cases. When county-level data are not available in some areas, we distribute the provincial data for each category using appropriate socio-economic statistics such as population, area, industrial output or gross domestic product, crop acreage, forest lawn area, food crop production, per capita income, the amount of chemical fertilizer and livestock. The distribution method employed has been used by many scholars [3,12,33].

As shown in Figure 1, the emission densities are higher in eastern and central China, such as in the provinces of Hebei, Shandong, Henan, Shanxi and Jiangsu, and are con-
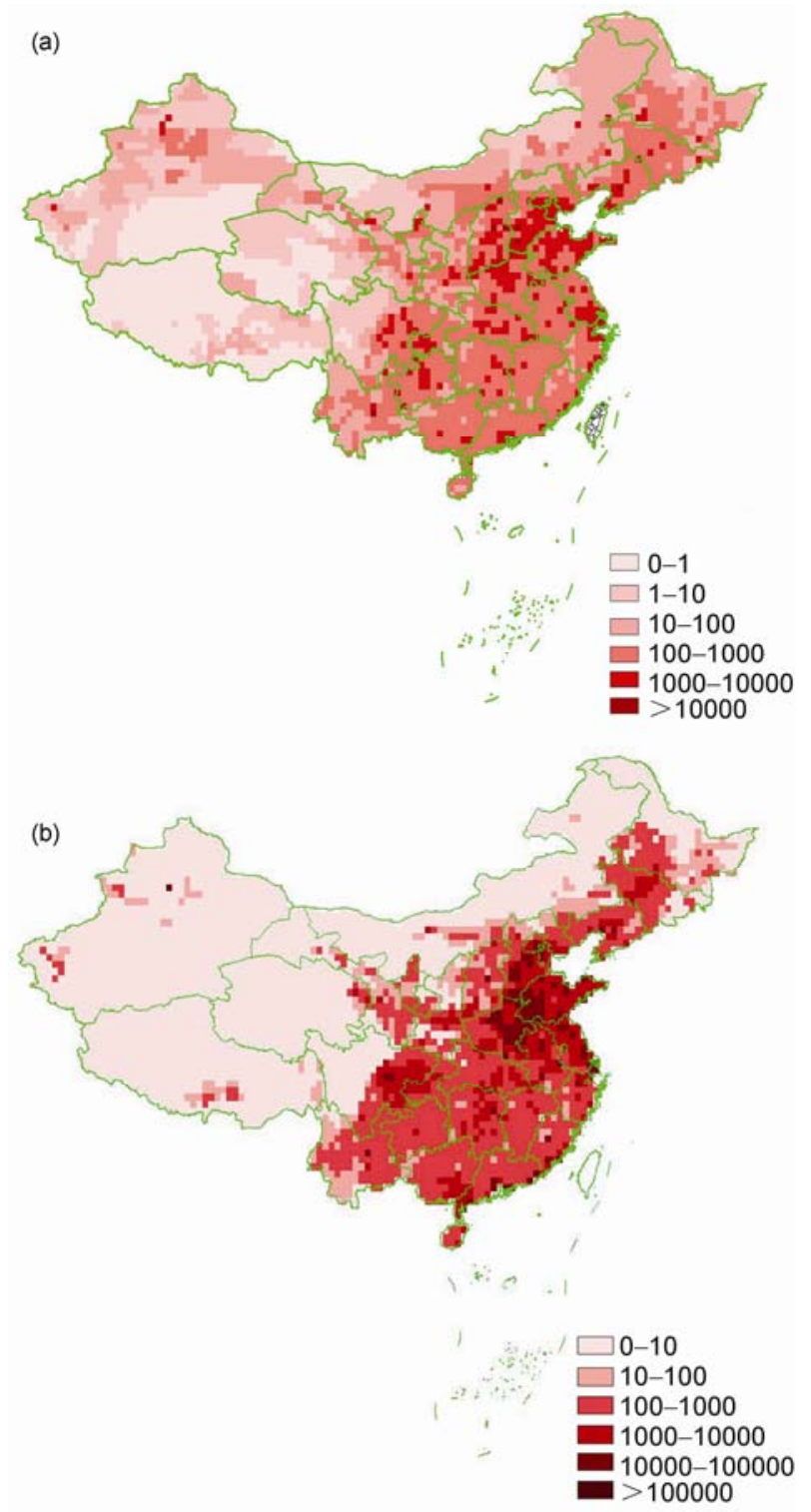

Figure 1 Gridded emissions for the year 2007 in China $\left(0.5^{\circ} \times 0.5^{\circ}\right.$, unit: t/grid). (a) $\mathrm{BC}$; (d) $\mathrm{NH}_{3}$. centrated in a curve around the agricultural and industrial heartland of China, from northeastern China to eastern China, while areas of lowest emission are in western China and Inner Mongolia, which have lower rural population densities and economic levels.

\subsection{Emission estimates by sectors}

Emissions estimated by sector are listed in Table 2. Large contributions to $\mathrm{PM}_{2.5}, \mathrm{BC}, \mathrm{OC}$ and $\mathrm{CO}$ emissions come from the industrial and residential sectors, while coal-fired power generation is the largest contributor to $\mathrm{SO}_{2}$ and $\mathrm{NO}_{x}$ emissions. $\mathrm{NH}_{3}$ primarily comes from poultry (livestock), human waste disposal and agricultural production, such as the use of chemical fertilizers. VOCs are mainly derived from biomass combustion, industrial solid-waste incineration, other waste-disposal processes and evaporating solvents used in printing.

\subsection{Comparison with other inventories}

There are significant improvements in our emission inventories compared with previous inventories. First, our inventories are based on the most recent data available (statistical data of fuel consumption, population and technology for 2007 provided by the Chinese government). Second, emission factors of biofuel combustion, residential coal combustion and vehicles were derived from local measurements.

Some scholars have compared earlier emission inventories for China [12,28] as summarized in Table 3. Except in the cases of $\mathrm{NH}_{3}$ and VOCs, our estimated emissions are close to those in previous inventories [12,28,59], but the emissions of different species and sectors are not the same. For example, the emission ratios by sector between this work for the year 2007 and Zhang's inventory [12] for the year 2006 are 1.02 (power generation), 0.50 (transport), 1.65 (industry) and 2.08 (residential). These differences can be largely attributed to the classification methodology for the emission sources. It should also be noted that emissions from coal combustion in rural industry, rural residents and open biomass combustion were significant but often underestimated in previous studies. The same underestimation has been noted by Wang et al. [33] for emissions in Shandong Province. Another important reason for these differences is that the latest government statistics and local emission factors in China are used in the present work. The emission ratios of the main sectors and the emission distribution processed using a geographical information system (Figure 1 ) in this work are consistent with relatively new inventories $[3,12,28,35]$.

\subsection{Seasonality of emissions}

One can expect seasonal variations $[3,34]$ in emissions due to (1) people in northern China burning coal or biofuel for 
Table 2 Summary of emission estimates by sector

\begin{tabular}{|c|c|c|c|c|c|c|c|}
\hline \multirow{2}{*}{ Species } & \multicolumn{7}{|c|}{ Emission by sector $\left(10^{4} \mathrm{t}\right)$} \\
\hline & Biomass burning & Power generation & Transport & Industry & Residential & & Total \\
\hline $\mathrm{PM}_{2.5}$ & 66.7 & 18.6 & 59.9 & 905.9 & 270.1 & & 1321.2 \\
\hline $\mathrm{BC}$ & 10.4 & 1.3 & 10.3 & 52.9 & 65.1 & & 139.9 \\
\hline $\mathrm{OC}$ & 43.3 & 1.7 & 14.5 & 80.5 & 154.6 & & 294.6 \\
\hline $\mathrm{SO}_{2}$ & 1.4 & 961.6 & 41.1 & 1995.2 & 159.1 & & 3158.4 \\
\hline $\mathrm{NO}_{x}$ & 50.5 & 939.3 & 256.7 & 886.0 & 192.5 & & 2324.8 \\
\hline $\mathrm{CO}$ & Waste disposal & Agricultural & Industry & Fertilizer production & & & \\
\hline \multirow[t]{2}{*}{$\mathrm{NH}_{3}$} & 957.6 & 362.3 & 248.0 & 33.8 & & & 1601.7 \\
\hline & Transport & Solvent use & Industry & Residential & Petrochemical production & Waste disposal & \\
\hline VOCs & 409.9 & 865.3 & 266.8 & 575.3 & 443.7 & 985.4 & 3546.4 \\
\hline
\end{tabular}

Table 3 Comparison of estimates of Chinese emissions

\begin{tabular}{|c|c|c|c|c|c|c|c|c|c|}
\hline \multirow{2}{*}{ Study } & \multirow{2}{*}{ Base year } & \multicolumn{8}{|c|}{ Emissions $\left(10^{4} \mathrm{t}\right)$} \\
\hline & & $\mathrm{PM}_{2.5}$ & $\mathrm{BC}$ & $\mathrm{OC}$ & $\mathrm{SO}_{2}$ & $\mathrm{NO}_{x}$ & $\mathrm{CO}$ & $\mathrm{NH}_{3}$ & VOCs \\
\hline This work & 2007 & 1321.2 & 139.9 & 294.6 & 3158.4 & 2324.8 & 16485.6 & 1601.7 & 3546.4 \\
\hline Zhang et al. [12] & 2006 & 1326.6 & 181.1 & 321.7 & 3102.0 & 2083.0 & 16688.9 & & 2324.7 \\
\hline Ohara [28] & 2003 & & 114 & 262 & 3660 & 1450 & 15800 & & \\
\hline Wei et al. [59] & 2005 & & & & & & & & 2010 \\
\hline Klimont et al. [60] & 2005 & & 136.6 & 281.2 & 3436.4 & 1692.6 & & & \\
\hline Lu et al. [61] & 2007 & & & & 3232.3 & & & & \\
\hline
\end{tabular}

heat but people in southern China not doing so, (2) emissions from poultry and livestock waste disposal in rural China being dependent on outdoor temperature, (3) open burning of agricultural waste in the field mainly occurring after the harvest period and (4) the fertilizer application time being closely related to phenological period and the farming season. Considering the above factors, monthly emissions at the national level are listed in Table 4 by species and strong seasonality is observed for $\mathrm{PM}_{2.5}, \mathrm{BC}, \mathrm{OC}$, $\mathrm{CO}, \mathrm{NH}_{3}$ and VOC emissions. As the emission of $\mathrm{NH}_{3}$ is more sensitive to temperature change, it has the strongest seasonal variation, with an emission ratio of 4.5 between its maximum (July) and minimum (December). Observation data for the seasonal variation in air pollutants have been discussed in detail $[62,63]$.

\section{Uncertainty in emission estimations}

Generally, the estimated uncertainty of emissions is a com- bination of the uncertainties in the emission factors for typical sources and the corresponding activity data. Uncertainty in the quantification methodology employed for emission inventories has been discussed in the literature $[64,65]$, but less progress has been made in the case of China.

We take guidance from the IPCC in analyzing the estimation uncertainty, and use an error propagation equation to estimate the overall uncertainty. There are two convenient rules for combining uncorrelated uncertainties under addition and multiplication. When uncertain quantities are combined by addition, the standard deviation of the sum is the square root of the sum of the squares of the standard deviations of the quantities that are added with the standard deviations:

$$
U_{\text {total }}=\frac{\sqrt{\left(u_{1} \cdot x_{1}\right)^{2}+\left(u_{2} \cdot x_{2}\right)^{2}+\cdots+\left(u_{n} \cdot x_{n}\right)^{2}}}{x_{1}+x_{2}+\cdots+x_{n}},
$$

where $U_{\text {total }}$ is the percentage uncertainty in the sum of the quantities and $x_{i}$ and $u_{i}$ are the uncertain quantities and the percentage uncertainties associated with them, respectively.

Table 4 Monthly emissions in China in $2007\left(10^{4} \mathrm{t}\right)$

\begin{tabular}{|c|c|c|c|c|c|c|c|c|c|c|c|c|}
\hline Species & Jan & Feb & Mar & Apr & May & Jun & Jul & Aug & Sep & Oct & Nov & Dec \\
\hline $\mathrm{PM}_{2.5}$ & 110.7 & 109.7 & 108.9 & 102.9 & 118.3 & 111.0 & 100.5 & 102.9 & 117.5 & 119.2 & 108.7 & 110.8 \\
\hline $\mathrm{BC}$ & 12.3 & 12.1 & 11.8 & 10.2 & 12.6 & 11.3 & 9.8 & 10.1 & 12.5 & 13.2 & 11.7 & 12.2 \\
\hline OC & 24.5 & 23.9 & 23.5 & 20.1 & 30.1 & 25.4 & 18.7 & 20.2 & 29.6 & 30.7 & 23.4 & 24.6 \\
\hline $\mathrm{SO}_{2}$ & 267.7 & 267.1 & 266.2 & 260.9 & 260.8 & 260.4 & 260.1 & 260.2 & 260.7 & 261.1 & 265.7 & 267.5 \\
\hline $\mathrm{NO}_{x}$ & 191.6 & 191.1 & 190.7 & 189.2 & 202.4 & 195.1 & 188.2 & 189.8 & 201.8 & 202.9 & 190.6 & 191.4 \\
\hline $\mathrm{CO}$ & 1348.0 & 1336.7 & 1317.3 & 1256.2 & 1559.9 & 1397.6 & 1218.9 & 1261.2 & 1545.9 & 1585.7 & 1315.6 & 1342.6 \\
\hline $\mathrm{NH}_{3}$ & 67.3 & 64.4 & 89.5 & 109.3 & 208.5 & 201.5 & 221.7 & 179.1 & 150.0 & 200.3 & 61.3 & 48.7 \\
\hline VOCs & 284.4 & 284.4 & 284.4 & 284.0 & 322.2 & 302.7 & 284.0 & 288.6 & 321.1 & 321.9 & 284.3 & 284.4 \\
\hline
\end{tabular}


When uncertain quantities are to be combined by multiplication, the same rule applies except that the standard deviations must all be expressed as fractions of the appropriate mean values:

$$
U_{\text {total }}=\sqrt{U_{1}^{2}+U_{2}^{2}+\cdots+U_{n}^{2}},
$$

where $U_{\text {total }}$ is the percentage uncertainty in the product of the quantities and $U_{i}$ is the percentage uncertainties associated with the different quantities.

We have made the following assumptions when estimating the uncertainty of the emissions. (1) Statistics and activity data taken from the National Bureau of Statistics and other government agencies [52,55,56] are believed to be highly reliable and are assigned the lowest uncertainty value of 5\%. (2) If emission factors are taken from quite limited sources, or a certain type of emission factor is unique, the uniform designed uncertainty is $200 \%$. Streets assumed that the uncertainty in the emission factor was 5\%-500\% in his inventories [3], which was much higher than that in this work. Since his inventories were developed for the whole of Asia, the applicability of his emission factors seems to be less certain. As the level of activity data has been improved and more local experimental data for emission factors been taken into account, the uncertainties in emissions from power plants and industrial and transport sectors are relatively low, but the uncertainties in emissions from biomass combustion and residential sectors remain high.

The estimated overall uncertainties of emissions in this work are listed in Table 5. For comparison, the estimated uncertainties of Streets et al. [3] and Zhang et al. [12] are also listed. It is seen that less uncertainty was achieved in this work, especially for $\mathrm{BC}, \mathrm{OC}$ and $\mathrm{CO}$ emissions. This is due to the difference in the assumed activity level and emission factors, particularly the lower uncertainty in emission factors as more local experimental data for emission factors were taken into account.

\section{Conclusions}

This paper presents detailed emission inventories for China in 2007 based on the latest fuel consumption data (including socioeconomic statistics and data on fossil and biomass fuels that were obtained from government agencies) and new emission factors obtained from local measurements. National and regional summaries of emissions were presented with $0.5^{\circ} \times 0.5^{\circ}$ resolution. The calculated total emissions in China were 13.212 Mt $\mathrm{PM}_{2.5}, 1.4 \mathrm{Mt} \mathrm{BC}, 2.946 \mathrm{Mt}$ OC,

Table 5 Uncertainty in emission estimates $( \pm \%)$

\begin{tabular}{ccccccccc}
\hline Inventory & $\mathrm{PM}_{2.5}$ & $\mathrm{BC}$ & $\mathrm{OC}$ & $\mathrm{SO}_{2}$ & $\mathrm{NO}_{x}$ & $\mathrm{CO}$ & $\mathrm{NH}_{3}$ & $\mathrm{VOCs}$ \\
\hline This work & 70.3 & 76.2 & 66.6 & 12.0 & 33.4 & 36.8 & 36.6 & 51.6 \\
Streets et al. [3] & & 360 & 450 & 16 & 37 & 185 & 72 & 130 \\
Zhang et al. [12] & 130 & 208 & 258 & 12 & 31 & 70 & & 68 \\
\hline
\end{tabular}

31.584 $\mathrm{Mt} \mathrm{SO}_{2}, 23.248 \mathrm{Mt} \mathrm{NO}_{x}, 16.017 \mathrm{Mt} \mathrm{NH}_{3}, 164.856$ Mt CO and $35.464 \mathrm{Mt}$ VOCs. The dominant contributions to $\mathrm{PM}_{2.5}, \mathrm{BC}, \mathrm{OC}$ and $\mathrm{CO}$ emissions are from industrial and residential sectors, while coal-fired power generation is the largest contributor to $\mathrm{SO}_{2}$ and $\mathrm{NO}_{x}$ emissions. $\mathrm{NH}_{3}$ is primarily from poultry (livestock) and human waste disposal and agricultural production processes, such as chemical fertilizer use. VOCs are mainly derived from biomass combustion, industrial solid-waste incineration and other waste disposal processes, and solvents used in printing. The emission densities are higher in eastern and central China, with emissions concentrated in a curve around the agricultural and industrial heartland of China, from northeastern to eastern China, while areas of lowest emission are in western China and Inner Mongolia, which have lower rural population densities and levels of economic development.

Except for $\mathrm{NH}_{3}$ and VOCs, the total emissions estimated here are roughly equal to those obtained in previous investigations, but they differ in terms of species and sector contributions. The uncertainties in the current inventories are found to be smaller than those of previous estimates. A strong seasonal dependence was observed for some species, mainly owing to seasonal changes in residential heating, the open burning of agriculture waste and fertilizer application.

This work was supported by the National Basic Research Program of China (2011CB403404) and the National R\&D Special Fund (Meteorology) for Public Welfare Industry (GYHY200706036).

1 Zhang X Y. Aerosol over China and their climate effect (in Chinese). Adv Earth Sci, 2007, 22: 12-16

2 Huebert B J, Bates T, Russell P B, et al. An overview of ACE-Asia: Strategies for quantifying the relationships between Asian aerosols and their climatic impacts. J Geophys Res, 2003, 108: 8633

3 Streets D G, Bond T C, Carmichael G R, et al. An inventory of gaseous and primary aerosol emissions in Asia in the year 2000. J Geophys Res, 2003, 108: 8809

4 Jacobson M Z. Strong radiative heating due to the mixing state of black carbon in atmospheric aerosols. Nature, 2001, 409: 695-697

5 Jacobson M Z. Control of fossil-fuel particulate black carbon and organic matter, possibly the most effective method of slowing global warming. J Geophys Res, 2002, 107: 4410

6 Menon S, Hansen J, Nazarenko L, et al. Climate effects of black carbon aerosols in China and India. Science, 2002, 297: 2250-2253

7 Ren R. On acid rain in China: Past, present and its future (in Chinese). J Beijing Polytech Univ, 1997, 23: 128-132

8 Wang T J, Jin L S, Li Z K, et al. A modeling study on acid rain and recommended emission control strategies in China. Atmos Environ, 2000, 34: 4467-4477

9 Terada $\mathrm{H}$, Ueda $\mathrm{H}$, Wang Z. Trend of acid rain and neutralization by yellow sand in east Asia-A numerical study. Atmos Environ, 2002, 36: 503-509

10 Zhang Y H, Shao K S, Tang X Y, et al. The study of urban photochemical smog pollution in China (in Chinese). Acta Sci Nat Univ Peking, 1998, 34: 392-400

11 Zhang Q, Z. K, Streets D G, et al. An anthropogenic PM emission model for China and emission inventory for the year 2001 (in Chinese). Prog Nat Sci, 2006, 16: 223-231

12 Zhang Q, Streets D G, Carmichael G R, et al. Asian emissions in 
2006 for the NASA INTEX-B mission. Atmos Chem Phys Discuss, 2009, 9: 4081-4139

13 Sun Q H, Lu Y Q, Fu L X, et al. Adjustment on NOx emission factors and calculation of $\mathrm{NO}_{x}$ emissions in China in the year 2000 (in Chinese). Tech Equip Environ Poll Control, 2004, 5: 90-94

14 Yang H W, Hu X L. Study on inventory system of sulfur dioxide emission in China (in Chinese). Energy Environ Prot, 2004, 18: 10-15

15 Wang L T, Zhang Q, Hao J M, et al. Anthropogenic CO emission inventory of Mainland China (in Chinese). Acta Sci Circum, 2005, 25: $1580-1585$

16 Wng W X, Wang W, Zhang W H, et al. Geographical distribution of $\mathrm{SO}_{2}$ and $\mathrm{NO}_{x}$ emission intensities and trends in China (in Chinese). China Environ Sci, 1996, 16: 161-167

17 Kato $\mathrm{N}$, Akimoto $\mathrm{H}$. Anthropogenic emission of $\mathrm{SO}_{2}$ and $\mathrm{NO}_{x}$ in Asia: Emission inventories. Atmos Environ, 1992, 26A: 2997-3017

18 Sun Q R, Wang M R. Ammonia emission and concentration in the atmosphere over China (in Chinese). Sci Atmos Sin, 1997, 21: 590598

19 Wang W X, Lu X F, Pang Y B, et al. Geographical distribution of $\mathrm{NH}_{3}$ emission intensities in China (in Chinese). Acta Sci Circum, 1997, 17: 2-7

20 Klimont Z, Streets D G, Gupta S, et al. Anthropogenic emissions of non-methane volatile organic compounds in China. Atmos Environ, 2002, 36: 1309-1322

21 Bouwman A F, Lee D S, Asman W A H, et al. A global high resolution emission inventory for ammonia. Glob Biogeochem Cycl, 1997, 11: 561-587

22 Aardenne J A, Carmichael G R, Levy H. Anthropogenic NOx emissionsin Asian in the period 1990-2020. Atmos Environ, 1999, 33: 633-646

23 Streets D G, Bond T C, Lee T, et al. On the future of carbonaceous aerosol emissions. J Geophys Res, 2004, 109: D24212, doi:10.1029/ 2004JD004902

24 Streets D G, Waldhoff S T. Present and future emissions of air pollutants in China: $\mathrm{SO}_{2}, \mathrm{NO}_{x}$ and CO. Atmos Environ, 2000, 34: 363374

25 Tonooka Y, A. K, H. H. NMVOCs and CO emission inventory in East Asia. Water Air Soil Pollut, 2001, 130: 199-204

26 Streets D G, Gupta S, Waldho S T, et al. Black carbon emissions in China. Atmos Environ, 2001, 35: 4281-4296

27 Streets D G, Tsai N Y, Akimoto H, et al. Sulfur dioxide emissions in Asia in the period 1985-1997. Atmos Environ, 2000, 34: 4413-4424

28 Ohara T A H K. An Asian emission inventory of anthropogenic emission sources for the period 1980-2020. Atmos Chem Phys, 2007, 7: 4419-4444

29 Tan Q, Chameides W L, Streets D, et al. An evaluation of TRACE-P emission inventories from China using a regional model and chemical measurements. J Geophys Res, 2004, 109: D22305

30 Bai N B. Gridded Emission of $\mathrm{CO}_{2}, \mathrm{SO}_{2}$, and $\mathrm{NO}_{x}$ from China. BeiJing: China Meteorological Press, 1996. 273

31 Tian H Z, Hao J M, Lu Y Q, et al. Inventories and distribution characteristics of $\mathrm{NO}_{x}$ Emissions in China (in Chinese). Chin Environ Sci, 2001, 21: 493-497

32 Zhao D, Wang A. Estimation of anthropogenic ammonia emissions in Asia. Atmos Environ, 1994, 28: 689-694

33 Wang X P, Mauzerall D L, Hu Y T, et al. A high-resolution emission inventory for eastern China in 2000 and three scenarios for 2020. Atmos Environ, 2005, 39: 5917-5933

34 Cao G L, Zhang X Y, Zheng F C. Inventory of black carbon and organic carbon emissions from China. Atmos Environ, 2006, 40: 6516-6527

35 Bond T C, Streets D G, Yarber K F, et al. A technology-based global inventory of black and organic carbon emissions from combustion. J Geophys Res, 2004, 109, D14203, doi:10.1029/2003JD003697

36 Editorial Board of China Electricity Yearbook. China Electricity
Yearbook (in Chinese). Beijing: China Electricity Press, 2008

37 Cooke W F, Liousse C, Cachier $\mathrm{H}$, et al. Construction of a $1^{\circ} \times 1^{\circ}$ fossil fuel emission data set for carbonaceous aerosol and implementation and radioactive impact in the ECHAM4 model. J Geophys Res, 1999, 104: 22137

38 Reddy M S, Venkataraman C. Inventory of aerosol and sulphur dioxide emissions from India: I-Fossil fuel combustion. Atmos Environ, 2002, 36: 677-697

39 Liousse C, Penner J E, Chuang C, et al. A global three-dimensional model study of carbonaceous aerosols. J Geophys Res, 1996, 101: 19411-19422

40 Turn S Q, Jenkins B M, Chow J C, et al. Element characterization of particulate matter emitted from biomass burning: Wind tunnel derived source profiles for herbaceous and wood fuels. J Geophys Res, 1997, 102: 3683-3699

41 Andreae M O, Merlet P. Emissions of trace gases and aerosols from biomass burning. Glob Biogeochem Cycl, 2001, 15: 955-966

42 Zhang J, Smith K R, Ma Y, et al. Greenhouse gases and other airborne pollutants from household stoves in China: A database for emission factors. Atmos Environ, 2000, 34: 4537-4549

43 Zhu S L. Study on emission factors of GHG and pollutants from rural stoves in developing countries (in Chinese). Renew Energy, 2004, 2: $16-19$

44 Du Q, Yang Y X, Zheng W, et al. The study of vehicle emission properties on real-road condition and the influence of some important factors (in Chinese). Trans CSICE, 2002, 20: 297-302

$45 \mathrm{Li} \mathrm{W}$, Fu L X, Hao J M, et al. Emission inventory of 10 kinds of air pollutants for road traffic vehicles in China (in Chinese). Urban Environ Urban Ecol, 2003, 16: 36-38

46 Shen M J, Hao J M, Wang L T. VOC emission situation and control measures of gas station in China (in Chinese). Environ Sci, 2006, 27 : 1473-1478

47 Cao G L, Zhang X Y, Gong S L, et al. Investigation on emission factors of particulate matter and gaseous pollutants from crop residues burning. J Environ Sci, 2008, 20: 501-555

48 Wang Y. The studies on the characteristic of motor vehicle particle emissions in Beijing district (in Chinese). J Jilin University, 2002

49 Chen Y J, Shen G Y, Bi X H, et al. Emission factors of carbonaceous particles and polycyclic aromatic hydrocarbons from residential coal combustion in China. Environ Sci Technol, 2005, 39: 1861-1867

50 Luo Y F, Li W H, Jiang Y, et al. Distribution of sulfur in coals of China (in Chinese). Coal Convers, 2005, 28: 14-18

51 Arndt R L, Carmichael G R, Streets D G, et al. Sulfur dioxide emissions and sectorial contributions to sulfur deposition in Asia. Atmos Environ, 1997, 31: 1553-1572

52 NBSC. China Statistical Yearbook 2007. Beijing: China Statistics Press, 2008

53 Editorial Board of China Rural Energy Yearbook. China Rural Energy Yearbook 2000-2008. Beijing: China Agricultural Press, 2008

54 Cao G L, Zhang X Y, Zheng F C, et al. Estimate the quantity of crop residues burnt in open field in China (in Chinese). Resour Sci, 2006, 28: 9-13

55 State Forestry Administration. China Forestry Statistics Yearbook 2008. Beijing: China Forestry Publishing House, 2008

56 Editorial Board of China Agriculture Yearbook. China Agriculture Yearbook 2008. Beijing: China Agricultural Press, 2008

57 Tian X R, Shu L F, Wang M Y. Direct carbon emissions from Chinese forest fires, 1991-2000 (in Chinese). Fire Saf Sci, 2003, 12: 6-10

58 Shea R, Shea B, Kauffman J, et al. Fuel biomass and combustion factors associated with fires in savanna ecosystems of South Africa and Zambia. J Geophys Res, 1996, 101: 523-551, 568

59 Wei W, Wang S, Chatani S, et al. Emission and speciation of non-methane volatile organic compounds from anthropogenic sources in China. Atmos Environ, 2008, 42: 4976-4988

60 Klimont Z, Cofala J, Xing J, et al. Projections of $\mathrm{SO}_{2}, \mathrm{NO}_{x}$ and car- 
bonaceous aerosols emissions in Asia. Tellus B, 2009, 61: 602-617

61 Lu Z, Streets D G, Zhang Q, et al. Sulfur dioxide emissions in China and sulfur trends in East Asia since 2000. Atmos Chem Phys Discuss, 2010, 10: 8657-8715

62 Zhang X Y, Wang Y Q, Zhang X C, et al. Carbonaceous aerosol composition over various regions of China during 2006. J Geophys Res, 2008, 113: D14111

63 Lin W L, Xu X B, Ge B, et al. Characteristics of gaseous pollutants at
Gucheng, a rural site southwest of Beijing. J Geophys Res, 2009, 114: D00G14

64 IPCC. Quantifying Uncertainties in Practice, Chapter 6: Good Practice Guidance and Uncertainty Management in National Greenhouse Gas Inventories. In: IES, IPCC, OECD, et al. Bracknell, UK, 1997

65 Zhong L J, Zheng J Y, Lei G Q, et al. Quantitative uncertainty analysis in air pollutant emission inventories: Methodology and case study (in Chinese). Res Environ Sci, 2007, 20: 15-20

Open Access This article is distributed under the terms of the Creative Commons Attribution License which permits any use, distribution, and reproduction in any medium, provided the original author(s) and source are credited. 